\title{
Evaluasi Pembelajaran Ekonomi Pada Kurikulum 2013 Di Sekolah Dasar Negeri 03 Sumbersari Kota Malang
}

\author{
Hendra Irawan ${ }^{1}$, Muhamad Juaini² \\ ${ }^{1}$ Pascasarjana-Pendidikan Ekonomi FE Universitas Negeri Malang \\ email: hendrawan0706@gmail.com \\ 2Prodi Pendidikan Ekonomi FISE Universitas Hamzanwadi \\ email:muhamadjuaini3@gmail.com
}

Received: 10 Maret, 2020; Accepted: 17 Mei, 2020; Published: 27 Juni, 2020

\begin{abstract}
Abstrak
Kualitas sebuah pembelajaran dapat diukur dari tingkat ketercapaian dari tujuan pembelajaran. pendidikan ekonomi adalah salah satu program pembelajaran yang harus mendapatkan perhatian penuh dari segi kualitas, sehingga tetap diaktualisasikan sebagai satuan pembelajaran yang memberikan makna tentang ilmu-ilmu ekonomi untuk kepada peserta didik bekal dalam berperilaku ekonomi yang rasional, bermoral dan alturistik. Penelitian ini bertujuan untuk mengevaluasi sejauhmana kualitas pembelajaran ekonomi di sekolah dasar SDN 03 Sumbersari Kota Malang. Penelitian ini menggunakan pendekatan penelitian evaluasi-kualitatif dengan model CIPP, meliputi: evaluasi segi context, input, process dan product/output. Hasil penelitian menunjukan bahwa pada kurikulum 2013 kedudukan pendidikan ekonomi masih terintegrasi dengan Ilmu Pengetahuan Sosial (IPS) dan dibelajarkan secara tematik. Minimnya tempat bagi mata pelajaran ekonomi berpengaruh secara tidak langsung terhadap menurunnya semangat guru untuk berinovasi dalam kegiatan pembelajaran maupun dalam melakukan kegiatan evaluasi hasil belajar. kelemahan dari aspek input pendidikan tersebut menjadikan aspek proses tidak terlaksana secara memadai dan pada akhirnya berdampak pula terhadap hasil belajar ekonomi yang rendah pada peserta didik.
\end{abstract}

Kata kunci: kurikulum 2013, pembelajaran ekonomi, sekolah dasar. evaluasi.

\begin{abstract}
The quality of a learning can be measured from the level of achievement of learning objectives. economic education is one of the learning programs that must receive full attention in terms of quality, so that it remains actualized as a learning unit that gives meaning to economic sciences for students in providing economic behavior that is rational, moral and alturistic. This study aimed to evaluate the extent of the quality of economic learning in elementary schools in SDN 03 Sumbersari, Malang. This study used a qualitative evaluation-research approach with the CIPP model, including: evaluating the aspects of context, input, process and product / output. The results showed that in the curriculum of 2013, The position of economic education was still integrated with Social Sciences (IPS) and thematically learned. the lack of space for economic subjects has an indirect effect on the decline in the enthusiasm of teachers to innovate in learning activities and in evaluating learning outcomes. Weaknesses of the aspects of educational input
\end{abstract}


make the aspects of the process not carried out adequately and ultimately also have an impact on low economic learning outcomes for students.

Keywords: Curriculum Of 2013; Economic Learning; Elementary School; Evaluation;

\section{PENDAHULUAN}

Pendidikan pada jenjang sekolah dasar sangat penting diselenggarakan sebagai upaya stategis yang ditempuh guna penanaman pengetahun dasar yang kuat, sehingga anak menjadi pribadi yang tangguh dan mandiri serta sesuai dengan cita-cita bangsa. sesuai dengan tujuan pendidikan yang diamanatkan Undang-Undang No.20 tahun 2003 pasal 17 ayat (1) yaitu; 1) pendidikan bertujuan untuk membangun dan meningkakan harkat dan martabat manusia, 2) pendidikan untuk menghasilkan manusia yang berkualitas yang menjamin pembangunan berkelanjutan, 3) pedidikan sebagai bekal menggali potensi yang ada untuk kemajuan dan kemandirian bagi peserta didik yang selaras dengan citacita bangsa. (Republik Indonesia, 2003).

Dalam rangka mencapai tujuan-tujuan itu, diperlukan pengelolaan yang terorganisir pada lembaga pendidikan untuk menghasilkan pendidikan yang baik dan selaras dengan tujuan negara. salah satu bentuknya adalah peningkatan kualitas dan mutu pendidikan yang didalamnya terdapat komponen-komponen, seperti, kurikulum, tenaga kependidikan, penggunaan media dan stategi pembelajaran yang efektif serta dilengkapi oleh proses evaluasi yang tepat untuk mengukur hasil pembelajaran. (Ramdhani, 2017)

Adapun secara umum ketercapaian kualitas dan mutu pendidikan tersebut adalah tanggung jawab penyelenggara pendidikan sepenuhnya. Pertama, pemerintah dituntut untuk menyusun kurikulum yang menyeluruh dengan memberikan porsi yang adil pada setiap bidang mata pelajaran dan ketepatan penentuan SK dan KD yang jelas. Kedua, lembaga pendidikan yang memiliki tanggung jawab membentuk tenaga pengajar yang profesional yang dibekali dengan pendidikan dan pelatihan yang luas sesuai bidangnya masing-masing. Ketiga, guru dituntut untuk mampu menciptakan suasana belajar yang nyaman, menghadirkan pengalaman belajar yang bermakna dan mampu mengaitkan 
kondisi lingkungan dan perkembangan peserta didik dengan materi yang diajarkan.(Prahara, Wahyono, \& Utomo, 2016)

Hal diatas sesuai dengan pendapat Qomar dalam Maya \& Lesmana, (2018) yang mengungkapkan bahwa pendidikan yang bermutu adalah memenuhinya prasyarat yang dituntut oleh pengguna jasa pendidikan (peserta didik) dan memiliki performa yang unggul sesuai kriteria yang telah ditentukan oleh stakeholders, baik dari sisi input, output maupun outcome. Dengan demikian, menghadirkan pendidikan yang berkualitas berlaku bagi setiap jenjang, termasuk berlaku pada jenjang sekolah dasar yaitu dengan menghadirkan pembelajaran yang berkualitas, kreatif dan menyenangkan bagi peserta didik.

Pendidikan ekonomi adalah salah satu program pendidikan yang mengkombinasikan komponen-komponen dalam proses pembelajaran yang mengajarkan tentang tata cara berprilaku ekonomi dan bertindak dalam memenuhi kebutuhan hidup pada peserta didik. Dengan demikian, pendidikan ekonomi adalah sebuah sistem pembelajaran yang tepat sebagai instrumen dalam menginternalisasikan nilia-nilai moral dalam berprilaku ekonomi. (Baskoro \& Wahyono, 2017)

Oleh sebab itu, pendidikan ekonomi sebagai alternatif pengurai ilmu-ilmu ekonomi sangat penting untuk terus diaktualisasikan dalam berbagai jenjang pendidikan, termasuk jenjang sekolah dasar sebagai upaya strategis untuk penanaman dan penguatan pengetahuan bagi peserta didik yang dimulai sejak dini.

\section{METODE PENELITIAN}

Penelitian ini menggunakan pendekatan penelitian evaluasi-kualitatif, yaitu sebuah pendekatan penelitian yang bertujuan mengukur keberhasilan suatu program, produk, kegiatan pembelajaran. (Danim, 2000). tujuan penelitian ini adalah menganalisis dan mengevaluasi praktek pendidikan ekonomi di sekolah dasar di SDN 03 Sumbersari Kota Malang. penelitian ini dilakukan sebagai perbandingan untuk menyempurnakan program pembelajaran yang sudah terlaksana. 
Model evaluasi yang digunakan adalah model evaluasi CIPP (context, input, process, product). Adapun evaluasi context dijadikan sebagai acuan untuk menentukan kebermaknaan atau nilai input, proses, dan produk/output pendidikan ekonomi. Evaluasi kualitas input meliputi: kurikulum, guru, dan sarana dan prasarana pendidikan ekonomi di sekolah dasar. Evaluasi process meliputi aspek: perencanaan, pelaksanaan dan evaluasi hasil pembelajaran yang dikembangkan dan dilaksanakan oleh guru dalam pendidikan ekonomi. Evaluasi product/output mencakup: hasil pembelajaran ekonomi yang akan dievaluasi pada domain kognitif, afektif dan psikomotorik.

Sumber data yang digunakan peneliti adalah sumber data primer dan data sekunder. sumber data primer yaitu kepala sekolah, guru-guru dan siswa. sedangkan sumber data sekunder, berupa: data-data pelengkap yang berkaitan dengan kajian penelitian. teknik pengumpulan data menggunakan observasi partisipan, wawancara mendalam (depth-in interview), dan studi dokumentasi. sedangkan teknik analisis data menggunakan model interaktif yang dikembangkan oleh Milles \& Hubermen (2009) yaitu dimulai dari tahap pengumpulan data, reduksi data, penyajian data dan menarik kesimpulan.

\section{HASIL PENELITIAN DAN PEMBAHASAN}

\section{Evaluasi context pendidikan ekonomi}

Evaluasi context diarahkan kepada beberapa aspek-aspek yang untuk menentukan arah keputusan tentang pengembangan pendidikan ekonomi di sekolah dasar, antara lain (1) tuntutan terpenuhinya landasan Undang-Undang (sistem ekonomi pancasila), (2) perlunya pertimbangan atas kondisi perkembangan kehidupan dan dinamika kehidupan masyarakat, (3) perlunya perhitungan patok duga (banch mark) atau muatan standar pendidikan ekonomi di sekolah dasar di negara yang telah mapan pendidikan ekonominya.

Secara garis besar ada 3 besaran data yang menjadi bahan untuk melakukan evaluasi context, antara lain:

\section{Tuntutan Terpenuhinya Landasan Undang-Undang (Sistem Ekonomi Pancasila),}


Hasil telaah tentang pasal 33 ayat 1-4 UUD 1945 (sistem ekonomi pancasila) yaitu, Berbagai pasal dan ayat dalam undang-undang dasar 1945 pada prinsipnya merupakan landasan legal-formal yang seharusnya menjadi landasan pelaksanaan pendidikan ekonomi di sekolah. Berikut telaah nilai-nilai yang terkandung pada pasal 33 UUD 1945, antara lain:

\section{Tabel 1. Telaah Pasal 33 UUD 1945}

\begin{tabular}{|c|c|}
\hline Pasal 33 & Nilai-nilai yang terkandung \\
\hline Pasal 33 ayat 1 & $\begin{array}{l}\text { Kegiatan ekonomi didasarkan pada asas kekeluargaan, } \\
\text { keadilan dan demokrasi ekonomi. }\end{array}$ \\
\hline Pasal 33 ayat 2 & $\begin{array}{l}\text { Kekayaan merupakan hak milik bersama bukan milik } \\
\text { pribadi dan negera sebagai pengelola, pengurus untuk } \\
\text { memenuhi hidup orang banyak. }\end{array}$ \\
\hline Pasal 33 ayat 3 & $\begin{array}{l}\text { Sumber daya alam didistribusikan berdasarkan asas } \\
\text { keadilan untuk pemerataan ekonomi. }\end{array}$ \\
\hline Pasal 33 ayat 4 & $\begin{array}{l}\text { Perekonomian nasional diselenggarakan berdasarkan } \\
\text { prinsip-prinsip kekeluargaan, kebersamaan, keadilan, } \\
\text { dan berkelanjutan. }\end{array}$ \\
\hline
\end{tabular}

Sumber: Hasil Olahan Peneliti 2020.

\section{Kesesuaian dengan Perkembangan Dan Dinamika Ekonomi Masyarakat.}

Seperti yang kita ketahui bersama bahwa pendidikan ekonomi adalah suatu pembelajaran yang urgen bagi setiap orang sebagai bekal diri dalam menjalani kehidupan bermasyarakat. karena diyakini bahwa setiap orang akan dihadapi dengan persoalan dan masalah-masalah ekonomi seperti: kelangkaan sumber daya untuk memenuhi kebutuhan dan memuaskan keinginan, penentuan pilihan dan pengambilan keputusan, kegiatan atau pekerjaan ekonomi dan tujuan ekonomi. Persoalan penentuan pilihan-pilihan tersebut menjadi sering keliru dipraktikkan. contohnya saja, kadang-kadang suatu barang dan jasa yang diprioritaskan untuk memenuhi kebutuhan hidup tidak serta-merta menjadi pilihan, dikarenakan ada faktor lain yang mendorongnya seperti, kesukaan (preferensi), gaya hidup, budaya dan lain sebagainya. sehingga, lebih memilih barang lain yang hanya sifatnya sebagai pemuas keinginan.

Fakta diatas menunjukan bahwa setiap orang memiliki problem dalam dirinya sendiri terkait dengan kemampuan penentuan keputusan atas pilihanpilihan yang tepat. Terlebih lagi ketika dihadapi dengan keterbatasan dan kelangkaan atas sumber daya yang memang sudah menjadi fakta kehidupan. pada 
saat itu juga, seseorang harus cermat dalam menentukan pilihan. Karena, disetiap pilihan atas sumberdaya tersebut, ada sumber daya lain yang harus dikorbankan (Dahl dalam Saptono, Tri, Rudijanto, Wahyono, \& Widjaja, 2016)

Ada beberapa alasan pentingnya pendidikan ekonomi diajarkan sejak dini. yaitu: pertama, pendidikan ekonomi diperlukan untuk membekali seseorang anak kemampuan dalam menentukan keputusan yang tepat atas pilihan-pilihan sumber daya. kedua, pendidikan ekonomi dibutuhkan untuk membekali seorang anak untuk memiliki perilaku ekonomi yang rasional, bermoral dan alturistik. (Wahyono, 2014) (Saptono et al., 2016)

\section{Patok Duga (Bench Mark) Standar Pendidikan Ekonomi Jenjang Sekolah Dasar Di Negara Yang Sudah Mapan Pendidikan Ekonominya.}

Salah satu negara sudah mapan adalah satunya adalah Amerika serikat, dimana kurikulum yang diterapkan mengacu pada standar isi yang ditentukan oleh Council Of Economic Education (CEE), yaitu pada jenjang sekolah dasar, pendidikan ekonomi dibelajarkan pada tingkat (grade) 4 sampai tingkat (grade) 12, antara lain:

1) Unit 1 Theme (1.1) scarcity and opportunity cost, (1.2) allocation and decision making, (1.3) business and decisions, (1.4) enterperneurship and bussines ownership:

2) Unit 2 Theme (2.1) consumers rule: (2.2) producers provide, (2.3) foundation of economic growth.

3) Unit 3 Theme (3.1) goverment role in a flourishing economy, (3.2) the role of teh federal goverment, (3.3) the role of money and banking. (3.4) national economic indicators.

4) Unit 4: Theme (4.1) international trade, (4.2) trade polices, (4.3) sosial problems: goverment of market solutions. (Economics, Overview, \& Release, 2019)

Sedangkan muatan standar pendidikan ekonomi di Indonesia berdasarkan kurikulum 2013 di sekolah dasar, sebagai berikut:

Tabel 2. Topik-Topik Pembelajaran Ekonomi Di Sekolah Dasar.

\begin{tabular}{ll}
\hline Kelas (class) & \multicolumn{1}{c}{ Topik-Topik (Topics) } \\
\hline Kelas 3 & (1) kerja sama dilingkungan; (2) jenis-jenis pekerjaan \\
& (3) kegiatan jual-beli, (4) sejarah uang dan kegunaan \\
& uang. \\
Kelas 4 & (1) pemanfaatan sumber daya alam sebagi sumber \\
& ekonomi (2) kegiatan ekonomi berdasarkan potensi
\end{tabular}


alam (3) pentingnya koperasi bagi kesejahteraan masyarakat.

Kelas 5 (1) usaha dan Kegiatan ekonomi di indonesia.

Kelas $6 \quad$ (1) globalisasi 2) ekspor dan impor.

Sumber: (Silabus IPS SD/MI 2019) (Lukita,dkk 2016)

Hasil telaah diatas dijadikan sebagai acuan untuk memahami pendidikan ekonomi disekolah dasar yang selama ini ada. Selain itu juga dipakai untuk menentukan tingkat urgensi atas aspek-aspek yang yang dievaluasi dalam upaya pengembangan pendidikan ekonomi di sekolah dasar.

Berdasarkan hasil analisis ketercapaian evaluasi pada aspek context pada program pendidikan ekonomi di SDN 03 Sumbersari Kota Malang dari keterterapan aspek context, antara lain:

1) Keterterapan pendidikan ekonomi disekolah belum maksimal, karena konten pembelajaran masih belum memenuhi latar belakang kehidupan yang sesuai dengan lingkungan tempat tinggal peserta didik. Hal tersebut dilihat dari praktik pembelajaran dan materi yang diajarkan, yaitu masih sifatnya terlalu abstrak dan universal, contohnya pada kelas 6 SD diajarkan tentang globalisasi dan ekspor-impor.

Oleh karena itu, Pendidikan ekonomi pada jenjang sekolah dasar, selayaknya mengakses sumber-sumber belajar dari lingkungan sekitar, baik dari lingkungan keluarga maupun lingkungan masyarakat sekitar, seperti mengajarkan tentang praktik-praktik gotong-royong dalam kegiatan ekonomi, menanamkan konsep kepedulian dalam ekonomi, memperkenalkan bentukbentuk kegiatan ekonomi dalam keluarga dan masyarakat serta usahanya dalam pemanfaatan potensi alam.

2) Keterterapan konten pengetahuan ekonomi yang dimiliki indonesia yaitu berkaitan dengan pasal 33 belum terselenggara sepenuhnya. Hal ini dapat dilihat dari minimnya praktik pendidikan ekonomi yang berlandaskan pasal 33 dan minimnya sumber belajar atau pustaka tentang ekonomi keindonesiaan. Karena, pada dasarnya pendidikan ekonomi yang diajarkan itu harus sesuai dengan ideologi bangsa, sehingga masyarakat juga dapat menyelesaikan secara mandiri persoalan ekonomi yang dihadapinya. 
Hal tersebut sesuai dengan pendapat (Wahyono, 2014) bahwa pada dasarnya pendidikan ekonomi dimaknai sebagai strategi penanaman ideologi untuk mempengaruhi perilaku ekonomi masyarkatnya. oleh karena itu setiap perubahan perilaku yang dimiliki oleh warga negara itu harus diselaraskan dengan sistem dan tata nilai yang berlandaskan ideologi bangsa tersebut.

\section{Evaluasi Kualitas input pendidikan ekonomi di sekolah dasar.}

Dari paparan data pada aspek masukan (input) termuat komponenkomponen pendidikan ekonomi yaitu: kurikulum, strategi dan metode pembelajaran, materi pembelajaran digunakan, tenaga pendidik yang terlibat serta sarana dan prasarana yang mendukung di SDN Sumbersari 03 Kota Malang. Adapun penjabarannya, antara lain:

\section{Kedudukan Pendidikan Ekonomi Dalam Kurikulum.}

Pendidikan ekonomi pada jalur pendidikan formal sudah diberikan kepada peserta didik sejak mulai mengenyam sekolah dasar yaitu berumur sekitar 7-11 tahun. Akan tetapi, pada jenjang ini pendidikan ekonomi masih terintegrasi dalam mata pelajaran ilmu pengetahuan sosial. Sebagaimana yang tertera pada kurikulum 2013 pada kelas I, II, III muatan IPS dintegrasikan pada kompetensi dasar Bahasa Indonesia, PPKn, dan Matematika. Sedangkan pada tingkat IV, V, dan IV mata pelajaran IPS menjadi mata pelajaran tersendiri. namun praktik pembelajarannya masih tergabung dan terpadu dengan mata pelajaran yang lain yang disajikan dalam bentuk tema-tema. Dengan demikian, dapat disimpulkan bahwa pada kurikulum 2013 pembelajaran ekonomi masih terintegrasi dengan mata pelajaran yang lainnya dan disajikan secara tematik.

Dengan demikian, bisa dikatakan bahwa dengan ketentuan dan ketetapan standar sesuai dengan penjelasan diatas mengenai kedudukan pendidikan ekonomi pada kurikulum 2013 hanya membahas garis-garis besar saja. keterbatasan tersebut secara tidak langsung menurunkan produktivtas guru untuk untuk berinovasi dalam kegiatan pembelajaran ekonomi maupun dalam melakukan kegiatan evaluasi hasil belajar. untuk itu perlu pengembangkan alternative standar yang lebih fleksibel dengan tetap mendorong guru untuk mengembangkan 
kreatifitas dalam pembelajaran ekonomi, sehingga pembelajaran ekonomi disekolah dasar terkesan luas dan tidak kaku. (Lestari, 2016)

\section{Pemahaman Guru Tentang Pendidikan Ekonomi.}

Berdasarkan hasil analisis data menunjukan bahwa pada komponen pemahaman guru tentang pendidikan ekonomi dinilai masih sangat kurang. Hal tersebut berasal dari keterangan guru-guru bahwa pembelajaran ekonomi yang diajarkan adalah masih berkisar pada materi sejarah uang, kegunaan uang, kegiatan ekonomi dan konsep pasar.

Hal tersebut dipicu oleh latar belakang (background) pendidikan atau program studi yang ditempuh di perguruan tinggi dulu, sehingga berpengaruh terhadap minimnya pengetahuan guru tentang pendidikan ekonomi. dampaknya para guru mengalami kesulitan dalam memahami muatan -muatan pendidikan ekonomi secara lebih luas. Hal tersebut kemudian berpengaruh juga terhadap performa guru dalam menyajikan dan membelajaran pendidikan ekonomi secara luas dan lebih menarik.

Sebagaimana hasil penelitian ini menunjukan bahwa Sebagian besar guru SD 03 Sumbersari Kota malang adalah guru kelas yang umumnya berlatar belakang lulusan program studi pendidikan dasar atau pendidikan guru sekolah dasar, dan jurusan-jurusan lainnya. menilik pada program pendidikan sekolah dasar (Dikdas) yang terselenggara di perguruan tinggi. Nampak bahwa tidak ada satu pun yang menawarkan mata kuliah atau konsentrasi bidang studi yang secara khusus mempelajari pendidikan ekonomi. adapun mata kuliah atau bidang studi konsentrasi hanyalah bidang studi Ilmu pengetahuan sosial (IPS), itu pun muatan pendidikan ekonomi sangatlah minim. oleh karena itu, penting dilakukan pembinaan dan pelatihan berkelanjutan bagi guru-guru kelas untuk memperbanyak khazanah pengetahuannya, khususnya berkaitan dengan pembelajaran-pembelajaran ekonomi untuk menunjang kemampun profesionalnya.

Sesuai dengan pernyataan diatas, penting dilakukan upaya-upaya peningkatan pada kemampuan profesional guru. karena semakin baik profesionalitas seorang guru. Maka akan semakin baik pula kemampuannya dalam 
menyajikan dan membelajarkan materi pelajaran ekonomi kepada peserta didik. (Baskoro \& Wahyono, 2017) Dengan demikian, dapat disimpulkan bahwa guru yang memiliki kemampuan yang memadai dari segi profesionalitas, akan berpengaruh terhadap peningkatan kualitas pendidikan yang diselenggarakan oleh intitusi.

\section{Sarana dan prasarana pendidikan ekonomi.}

Aspek-aspek penilaian pada sarana dan prasarana pembelajaran ekonomi diadaptasi dari instrument standar sarana dan prasarana sesuai dengan ketentuan menteri pendidikan nasional menteri No.24 tahun 2007. Secara garis besar untuk sarana dan prasarana kelas dinilai dari perabotan kelasnya, peralatan pendidikannya, dan media pembelajarannya. Untuk laboratorium aspek yang dinilai terkait dengan peralatan dan perlengkapan yang tersedia didalamnya.

Adapun kondisi sarana dan prasarana di SDN Sumbersari 3 Kota Malang terdiri dari 6 (enam) ruang kelas belajar yang semuanya dilengkapi LCD proyektor, 2 (dua) laboratorium dan 1 (satu) ruangan perpustakaan yang dilengkapi oleh buku tematik terpadu Kurikulum 2013, buku-buku kurikulum KTSP. selain itu juga, guru-guru mengunakan media internet sebagai tambahan materi pembelajaran.

Berdasarkan hasil observasi ada beberapa kekurangan dari segi sarana dan prasarana penunjang pembelajran ekonomi, yaitu 1) minimnya alat peraga pembelajaran ekonomi, 2) belum tersedianya laboratorium ekonomi sebagai sarana atau wadah peserta didik berkreasi dan melakukan praktik-praktik ekonomi dan 3) minimnya sumber belajar ekonomi, khususnya konten-konten ekonomi keindonesiaan.

Hal tersebut sesuai dengan hasil wawancara bersama dewan guru yang membuktikan bahwa sekolah kekurangan ruangan untuk melaksanakan pembelajaran ekonomi secara lebih luas baik melalui penyampaian teori atau praktek. Kegiatan pembelajaran ekonomi di sekolah tersebut hanya terbatas di ruang kelas, teras sekolah dan ruang perpustakaan.

Hal tersebut menjadi masukan bagi program pendidikan ekonomi di SDN Sumbersari 03 Kota Malang agar meningkatkan aspek input terutama pada 
komponen sarana dan prasarana. Sekolah perlu mengadakan penambahan ruangan laboratorium ekonomi, seperti koperasi dan laboratorium ekonomi kreatif untuk menunjang pembelajaran ekonomi dalam konteks keindonesiaan atau yang berbasis global guna meningkatkan kreativitas anak serta menumbuhkan minat berwirausaha sejak dini.

\section{Evaluasi Kualitas proses meliputi perencanaan, pelaksanaan dan evaluasi pendidikan ekonomi}

Dari paparan data pada aspek proses, meliputi kegiatan perencanaan, pelaksanaan dan evaluasi hasil belajar pada SDN Sumbersari 03 Kota Malang. Adapun penjabarannya antara lain:

\section{Perencanaan Pembelajaran}

Perencanaan pembelajaran, yaitu penyusunan jadwal pembelajaran. Berdasarkan salinan peraturan permendikbud no.23 tahun 2017 menunjukan bahwa pada kurikulum 2013 kegiatan pembelajaran dilaksanakan selama 6 hari dan sekitar 8 jam dalam sehari. sementara khusus mata pelajaran ekonomi yang terintegrasi dalam pembelajran IPS memiliki 3 jam pelajaran/minggu. jumlah jam tersebut jauh lebih rendah dengan mata pelajaran yang lainnya, seperti pendidikan agama, KWN, Matematika dan lainnya. dengan jumlah jam tersebut membuktikan bahwa pendidikan ekonomi masih minim diberikan porsi dan tempat yang layak dalam jenjang sekolah dasar.

\section{Pelaksananan Pembelajaran.}

Adapun komponen-komponen didalam pelaksanaan pembelajaran, antara lain:

1. Rencana Perangkat Pembelajaran (RPP),.

Pada komponen ini, guru-guru di SDN sumbersari 03 malang telah melakukan penyusunan rencana kegiatan pembelajaran (RPP). adapun tahap tahapnya dimulai dari berdo'a sebagai pembukaan, guru melakukan apersepsi, kegiatan inti dan terakhir dilakukan proses evaluasi untuk mengukur dan menilai hasil belajar siswa. 
Berdasarkan hasil penelitian tersebut diatas menunjukan bahwa penyusunan rencana perangkat pembelajaran oleh guru wajib dilakukan sebagai pedoman dan panduan dalam kegiatan pembelajaran. Setiap guru membuat RPP sebelum melakukan pembelajaran dengan tujuan adanya kesesuaian perangkat pembelajaran yang digunakan dengan tema-tema yang akan diajarkan ke siswa.

Penyusunan RPP yang dilakukan oleh guru-guru adalah sah adanya dan merupakan bagian dari beban guru. Akan tetapi, perlu diketahui bahwa penyusunan RPP bukan semata-mata menjadi panduan wajib (patokan) pembelajaran, karena hal demikian akan membuat setiap tahap-tahap proses pembelajaran terkesan kaku, monoton dan tidak flexibel.

2. Strategi Pembelajaran,

Berdasarkan hasil penelitian menunjukan bahwa dalam mempermudah proses pembelajaran ekonomi di sekolah. guru-guru menggunakan strategi dan metode pembelajaran yang variatif. salah satunya adalah metode pembelajaran simulasi pasar yang dilaksanakan secara bergiliran. Dalam topik pembelajaran ini guruguru SDN 3 sumbersari baik dari kelas I-IV menghimbau kepada para peserta didik untuk membawa jajanan atau kue dari rumah untuk dijual kembali disekolah, kemudian yang menjadi pembelinya adalah peserta didik dari kelas IIV juga. Hal ini dilakukan guru untuk memberikan pemahaman tentang pasar dan proses jual beli serta memperkenalkan bentuk asli dari proses jual-beli. adapun tujuan dari penggunaan strategi pembelajaran simulasi adalah untuk menumbuhkan karakter pada siswa seperti karakter kemandirian, kejujuran dan kerja keras.

Selain itu juga, guru-guru mengunakan metode pembelajaran yang bervariatif dengan bantuan media yang dapat digunakan. hal tersebut dilakukan guna mengurangi kejenuhan pada peserta didik. Sesuai dengan pendapat sanjaya (2006) dalam mengimplemntasikan sebuah rencana, diperlukan sebuah cara atau metode yang dapat digunakan sebagai digunakan untuk mencapai tujuan-tujuan yang telah disusun.

3. Evaluasi pembelajaran 
Evaluasi pembelajaran hadir sebagai sebuah solusi dalam menemukan kelebihan dan kelemahan-kelemahan dari proses pembelajaran yang sudah dilaksanakan. Dalam hal ini adalah guru mengukur dan menilai hasil belajar peserta didik selama periode tertentu untuk menentukan tingkat capaian keberhasilan peserta didik dalam mengikuti sebuah pembelajaran. apakah peserta didik layak dikatakan sudah memiliki pemahaman, naik kelas atau dapat mengikuti pembelajaran selanjutnya. Oleh karena itu dalam evaluasi ada proses mengukur dan menilai yang dilakukan oleh guru baik itu berkaitan dengan hasil belajar peserta didik maupun keefektifan pelaksanaan pembelajaran yang dilakukan oleh guru.

Berdasarkan hasil penelitian menunjukan bahwa evaluasi yang dilakukan oleh guru adalah evaluasi sumatif yaitu bentuk penilaian yang yang dilakukan dalam menilai dan mengukur hasil belajar peserta didik, seperti ulangan harian, ulangan tengah semester (UTS), dan ulangan akhir semester (UAS). proses ini dilakukan untuk mengetahui sejauh mana hasil pembelajaran peserta didik. selain itu juga, penilian ini sebagai acuan mengetahui keberhasilan guru dalam melaksanakan proses pembelajaran.

Berdasarkan hasil penelitian diatas dapat membuktikan bahwa dalam melakukan proses evaluasi, para guru masih fokus pada pembentukan aspek kognitif saja. padahal ranah sikap (karakter) dan psikomotorik (keterampilan) menjadi basis pembentukan perilaku ekonomi yang rasional.

Sesuai dengan pendapat yang dikemukakan Wahyono (2014) pengembangan pendidikan ekonomi pada berbagai jenjang dan jalur, selayaknya harus bertujuan untuk menumbuhkan sikap dan perilaku yang sesuai dengan tuntunan keluarga dan lingkungan masyarakat sekitar dengan cara mempraktekan perilaku ekonomi yang rasional, bermoral dan alturistik (kepedulian dan kasih sayang).

\section{Evaluasi kualitas produk/output pembelajaran ekonomi}

Berdasarkan analisis data yang dilakukan oleh peneliti menunjukan bahwa SDN 03 sumbersari memiliki sasaran dan tujuan pembelajaran yang lebih luas yaitu pembentukan karakter pada peserta didik sebagai sebuah hasil belajar ekonomi. Adapun karakter-karakter yang dikembangkan, antara lain: 
1) Kejujuran dan Integritas. Hal ini ditanamkan melalui strategi pembelajaran yang digunakan dikelas seperti kelas pasar, yang dimana siswa di tuntut untuk berlaku jujur dalam melakukan transaksi jual-beli.

2) Kemandirian. Hal ini ditanamkan melalui praktik ekonomi kreatif, yaitu siswa dituntuk untuk memiliki kreatifitas. Salah satunya dalah menghasilkan produk berupa "Lampu Emergency" yang terbuat dari Charger HP, lampu dan perlengkapan lainnya. Kemudian, produk berupa "Lampu Emergency" diseleksi yang sekiranya layak untuk diperjual-belikan. Kemudian para guru memfasilitasi mereka dengan menjualkan tersebut melalui media sosial.

Berdasarkan hasil penelitian diatas dapat membuktikan bahwa dalam melakukan proses evaluasi, para guru tidak hanya fokus pada pembentukan aspek kognitif saja. akan tetapi sudah menyentuh ranah sikap dan karakter. Akan tetapi, evaluasi yang yang diberikan oleh guru kepada peserta didik belum sepenuhnya menyentuh pada karakter-karakter ekonomi keindonesiaan, sehingga peserta didik belum benar-benar dibekali dengan moral dan perilaku sesuai identitas bangsa yang mengacu kepada pasal 33 Undang-undang 1945, yaitu penanaman karakter kepedulian dalam aktivitas ekonomi yang dilandasi oleh alturisme (sikap lebih mementingkan kepentingan orang lain dari pada dirinya sendiri, perasaan ingin bermanfaat terhadap orang lain) dan perasaan iba dan kasih-sayang (compasionate) pada peserta didik yang dikembangkan melalui praktik-praktik ekonomi berbasis kekeluargaan.

\section{KESIMPULAN}

Dengan demikian, sesuai hasil telaah dan penilaian evaluasi contex, process, input dan output/product. Pelaksanaan kurikulum 2013 pada pembelajaran ekonomi di sekolah dasar SDN 03 Sumber Sari Kota Malang secara keseluruhan sudah sesuai dengan ketentuan-ketentuan Permendikbud. akan tetapi, masih menghadapi beberapa kelemahan pada semua aspek- aspeknya. Dikaitkan dengan penentuan standar pelaksanaannya, ditemukan kelemahan dari aspek input pendidikan yang menjadi akar permasalahnya yaitu, guru masih terbelenggu oleh peraturan dan kebijakan oleh kementerian pendidikan dan kebudayaan yang berkaitan dengan ketetapan standar proses. sehingga, menjadikan aspek proses 
tidak terlaksana secara memadai dan pada ujungnya juga akan mengakibatkan hasil belajar ekonomi peserta didik menjadi lebih rendah.

\section{DAFTAR RUJUKAN}

Baskoro, H. D., \& Wahyono, H. (2017). Evaluasi Program Pembelajaran Guru Mata Pelajaran Ekonomi Sekolah Menengah Atas (Sma) Negeri Dan Swasta Di Kabupaten Tulungagung. Jurnal Pendidikan Ekonomi, 10(2), 118-125. https://doi.org/10.17977/um014v10i22017p118

Economics, J. A., Overview, C., \& Release, I. (2019). JA Economics ${ }^{\circledR}$ Course Overview and Outline. 1-8.

Marshall, A., Pendidikan, M., \& Pluralistik, E. (n.d.). Mereka pendidikan ekonomi pluralistik.

Maya, R., \& Lesmana, I. (2018). PEMIKIRAN PROF. DR. MUJAMIL QOMAR, M.AG. TENTANG MANAJEMEN PENDIDIKAN ISLAM. Islamic Management: Jurnal Manajemen Pendidikan Islam. https://doi.org/10.30868/im.v1i2.281

Prahara, R., Wahyono, H., \& Utomo, S. (2016). Kualitas Pembelajaran Ekonomi Di Sman Dan Man Malang Raya. Jurnal Pendidikan - Teori, Penelitian, Dan Pengembangan, 1(12), 2266-2271. https://doi.org/10.17977/jp.v1i12.8225

Ramdhani, M. A. (2017). Lingkungan pendidikan dalam implementasi pendidikan karakter. Jurnal Pendidikan UNIGA.

Republik Indonesia. (2003). Undang-Undang Sistem Pendidikan Nasional No. 20 Tahun 2003. Sekretariat Negara. https://doi.org/10.16309/j.cnki.issn.10071776.2003.03.004

Saptono, L., Tri, E., Rudijanto, D., Wahyono, H., \& Widjaja, U. M. (2016). Pengembangan Kurikulum Pendidikan Ekonomi Untuk Meningkatkan Literasi Ekonomi Siswa Sekolah Dasar.

Universitas, S. P., Malang, U. N., Brawijaya, U., \& Dasar, S. (2016). No Title. 459-470. 